\title{
EXPLORING TOURISM POSSIBILITIES USING GIS-BASED SPATIAL ASSOCIATION METHODS
}

\begin{abstract}
Aleš RUDA ${ }^{1}$
DOI: 10.21163/GT_2016.112.09

ABSTRACT:

This paper represents particularly important study for an effective design and implementation of regional policies. It also shows the potential application of spatial statistics analysis to compare and contrast patterns of spatial associations in interrelated measures of tourism performance. In case of sustainable tourism development attributes related to tourism potential and environmental protection have been considered. The three data sets (tourism potential, specific environmental value and tourism infrastructure load) have been proposed as composite indicators. By using multicriterial decision-making techniques and spatial associations of those different variables, it was possible to identify local disparities in tourism potential and propose final appearance of community groups linked by similar characteristics. Moran's I statistic and Getis-Ord Gi* statistic helped to distinguish detailed disparities between clustered regions and point out significant drivers of the NízkýJeseník Highlands. Finally, five groups of municipalities with similar attributes were created and using hot spot analysis significant cores were identified and pointed out as key spots for further tourism development.
\end{abstract}

Key-words: GIS, Tourism development, Spatial decision making support, Grouping analysis, Moran's I, Getis-Ord Gi* .

\section{INTRODUCTION}

Considering global and regional perspective, tourism issues are discussed very intensively. States or supra-regions want to identify the actual position of tourism industry in national economy and through destination management provide potential investors and visitor direct insight into area and its territorial capital. Experts in regional development are also interested in the relationship between tourism and the environment, and so it is appropriate to give special attention to the discussion and implementation of sustainable tourism development especially when the attention has increased with obvious effects of mass tourism on the environment of target destinations (Butler, 1993, 1999). The very concept of sustainable tourism is difficult to define because there are a number of different understandings supported by scientists' assurances that their definition is the most appropriate. It is clear that the role of information technology in tourism has been an issue of growing importance during last decades. IT applications in tourism are mostly related to distribution, banking and reservation systems but the function provided by decision making support systems still lags. This gap could be filled in by using spatially oriented systems to assist sustainable tourism management in existing destinations. Geographical information systems (GIS) in tourism can help to build tourism resource inventories, strengthen safeguarding the environment during tourism planning, manage and control tourism development in relation to conflicting demands, monitor tourism activities, provide

\footnotetext{
${ }^{1}$ Mendel UniversityUniversity in Brno, Faculty of Regional Development and International Studies, 61300 Brno, Czech Republic, ales.ruda@ seznam.cz.
} 
information about tourism destinations on the Internet using map-based information, understand tourism behaviour through tourist time space analysis, raise awareness on the importance of community involvement and participation during the development or simulate and model spatial outcomes of different topics. Among demand-led benefits mentioned to derive from GIS outcomes cost savings, better quality of data or timely and accurate information might be identified. Regarding future development of an existing tourism destination, building a new one need mathematically modelled scenarios for planning and decision making. In this case it is highly recommended to consider tourism potential, specific environmental area value and tourism infrastructure load (Ruda, 2010). In a local scale the cooperation between municipalities (regions) on the same level and their community driven development is an issue of high priority. This approach requires detailed geostatistical analysis of given area and geoinformatically based proposal of groups of municipalities. The paper develops decision making model using spatial association detection methods of proposed composite indices (tourism potential, specific area environmental value and tourism infrastructure load) for finding both outliers and natural clusters within municipalities enabling possible collaboration in tourism issues. The goal of the paper is to implement spatial association methods as significant geostatistical tool for identifying possible cooperation between administrative units in tourism issues.

\section{GIS BASED TOURISM MAPPING AND ASSESSMENT}

Public acknowledgment of the role of GIS and its implications in regional development has led to the development of several approaches within tourism/recreation issues the same as information systems in knowledge based economy (Ruda, 2011). Using literature review, GIS driven methodology comprises especially five tourism based applications (1) full tourism (recreational) potential assessment or evaluation of its partial component, (2) terrain suitability mapping for a given recreation activity, (3) tourism and recreation assessment as a part of cultural ecosystem services, (4) tourism and recreation impacts assessment considered as a conflict with natural resources mostly using spatial decisionmaking techniques and (5) tourism carrying capacity evaluation. GIS applications range encompassing tourism suitability mapping (also called as tourism potential identification or territorial capital assessment within tourism sector) have appeared in $80 \mathrm{~s}$ of the $20^{\text {th }}$ century based on McHarg's (1969) work and automated with the development of computer cartography (Manly, 2004). This approach has also been used for GIS-based methodologies applied in land use planning (Ruda, 2013). The first GIS-integrated concept of recreation suitability index was developed by Levinsohn et al (1987) although Kliskey (2000) mentioned Duffield and Coppock's (1975) computer based delineation of recreational landscapes as the first effort working with spatial representations. More inventorying is approach of Gobster et al (1987) focused on identifying recreation opportunities using physical, social and managerial variables. Compared to above mentioned approaches connected mostly with nature environment Bína (2010) and Ruda (2010) proposed tourism potential based on all necessary components comprising localization (natural and culturehistorical factors) and realization (usability and accessibility factors) assumptions. The internationally acknowledged division of potential into localization and realization opportunities originates in the works of Mariot (1969, 1971, 1973). Bína's methodology (2010) uses not well justified expert opinions weights and this might be misleading. A certain disadvantage of the methodology above is also its application in administrative regions and austerity of calculation in lower than local level (Magyari-Sáska, 2014; Ruda, 
2010; Ruda \& Pokladníková, 2016). Terrain suitability mapping represents a wide platform for development of many spatially based methodologies. These approaches differ in the use of source data and chosen procedure of computation. Kliskey (2000) used a principal component analysis of a recreation attitudinal scale for snowmobiling administered through questionnaire survey and completed with weights derived from the principal component scores. Miller, Aspinall and Morrice (1992) analysed elevation characteristic for terrain visibility indication. Using a combination of different GIS-based techniques (Kernel density, regression analysis and neighbourhood analyses), Chhetri and Arrowsmith (2008) modelled a recreational potential of Nature-based tourist destinations. Relatively young but not quite new is an assessment of tourism potential as a component of ecosystem services including all non-material ecosystems outputs having symbolic, intellectual or cultural significance (Haines-Young \& Potschin, 2011). The goal of many surveys involving tourism as an ecosystem service is to determine which landscape factors make a specific site (destination area) more attractive. The type of tourism that is mostly approached is nature or culture-based tourism (Deng, King \& Bauer, 2002). Authors (Buijs, Pedroli \& Luginbühl, 2006; Gobster, 2001; Faggi et al, 2011). Weyland and Laterra (2014) estimated outdoor recreational potential level using a quantile multiple regression, especially analysis of the 0.9 quantile of campsite density with landscape metrics determinants. Within ecosystem services they highlight that assessment of recreation and ecotourism has followed four key approaches: mapping of visitor expenditures, mapping potential recreation areas based on the natural habitat and the accessibility of the area, mapping benefits from tourism and mapping recreation and landscape values evaluating stakeholders' engagement. Considering the importance of visitors and experts within tourism studies, participatory methods increase the level of final outputs (Boyd \& Banzhaf, 2007). This idea was further processed by Nahuelhual et al (2013) who proposed multicriteria analysis calculating through specific spatial criteria recreation and ecotourism potential and recreation and ecotourism opportunities reflecting all aspects of tourism and carrying capacity measured by visitors per hectar. In the context of spatial decision-making single objective evaluation prevails. Within this process the key is to identify relevant criteria (factors and constraints) allowing and determining the suitability for a specific tourism (recreation) activity. Similar but technologically easier solutions brings Ruda (2010) examining regression relation between tourism potential and tourism infrastructure load and Weyland and Laterra (2014) searching level of dependence between campsite density and environmental variables respecting regression relation with recreation potential. The sustainability in tourism should not be understood as preservation of the environment for future generations, but also the quality of life of the local people linked to tourism business must be taken into account (Malik \& Bhat, 2015). Considering all above mentioned studies, modelling of tourism potential still lacks a general assessing methodology despite that numerous of studies such as simulation model of social carrying capacity (Lawson et al, 2002; Egresi and Kara, 2015), recreation opportunity spectrum (USDA Forest Service, 1989), uniqueness ration of landscape features (Leopold, 1969) have been developed. All mentioned results can be projected in administrative regions (polygons in vector data format) or purpose-designed square grid which should be enough illustrating for local level. In case we look for a common denominator at the regional level, regionalization procedures especially cluster or grouping analysis bring useful aggregation showing possible collaborations between reference units or administrative regions. 


\section{DATA AND METHODOLOGICAL BACKGROUND}

The concept of research methodology determines key variables influencing the role of the municipality in tourism business and examines spatial patterns in their distribution in order to find spatial associations referring to common attributes of reference units. These key variables were designed as composite indices (data sets) - tourism potential, specific environmental value and tourism infrastructure load - and have been developed for sustainable tourism planning in a destination area. The research methodology was applied in the Nízký Jeseník Highlands which is an area not highly loaded by tourism activities but situated between important tourism destinations in the Czech Republic (the Hrubý Jeseník Mts. to the northwest and the Moravian-Silesian Beskydy to the east). The development of composite indices was based on the principle of weighted index models (Corodescu, 2016 There are also some limitations identified during the model development.

Considering administrative regions as a key reference unit, municipalities were used for data analysis. First, using municipalities as basic reference units has simplified the modelling process but enables to plan across these administrative units. Furthermore, perception is also influenced by selected variables within the model, although they were chosen in order to satisfy necessary attributes present in the study area. Secondly, used weights were estimated based on university students ranking educated in tourism issues. Thirdly, using different spatial weight matrices during grouping analyses can bring varying results. Basic input data was taken from Data200 geodatabase, CORINE land cover 2006 or primarily collected in the field during 2013 - 2014. In order to describe data sets proposal, explanation of used terminology is necessary. Thematic group (for instance protected areas within specific environmental area value index) is represented by partial data (themes - natural parks, small protected areas etc.) Individual themes represent examined features applied to each municipality as their proportion, density or computed indicator value. Category is an individual characteristic necessary for the theme value calculation (for example: forest areas within Land use theme). In case of data processing, similar way of computation (Fig. 1) was used for all indices.

Each municipality was scored based on reclassification into five classes using Natural breaks algorithm, weighted and summarized and reclassified by the same way. This enabled to describe each factor and each assumption individually and assign points (1-5) on the level of factors and assumptions as well. Regarding previous derivations, indices' value was computed as a weighted sum of different indicators. Let's observe the values of $p$ statistical variables on $n$ areal units of a study area. Based on Anselin (1995) these data are associated with spatial econometrics techniques. According to Fortin and Dale (2009) entities are rarely randomly distributed in natural systems. More than that, we can see different levels of clustering. Dependence of specific entity presence in space on the occurrence of the same entity in closer distance assumes a presence of spatial autocorrelation. If entities are randomly distributed across the space no spatial autocorrelation can be examined. Tobler (1970) described that attributes of closer locales tend to be more similar than distant ones. Concerning the spatiality, adjacent values of spatial data showing the similarity illustrate positive spatial autocorrelation. Opposite the situation when adjacent values are dissimilar, then it declares negative autocorrelation. 
I. Point classification according to sum of weighted values

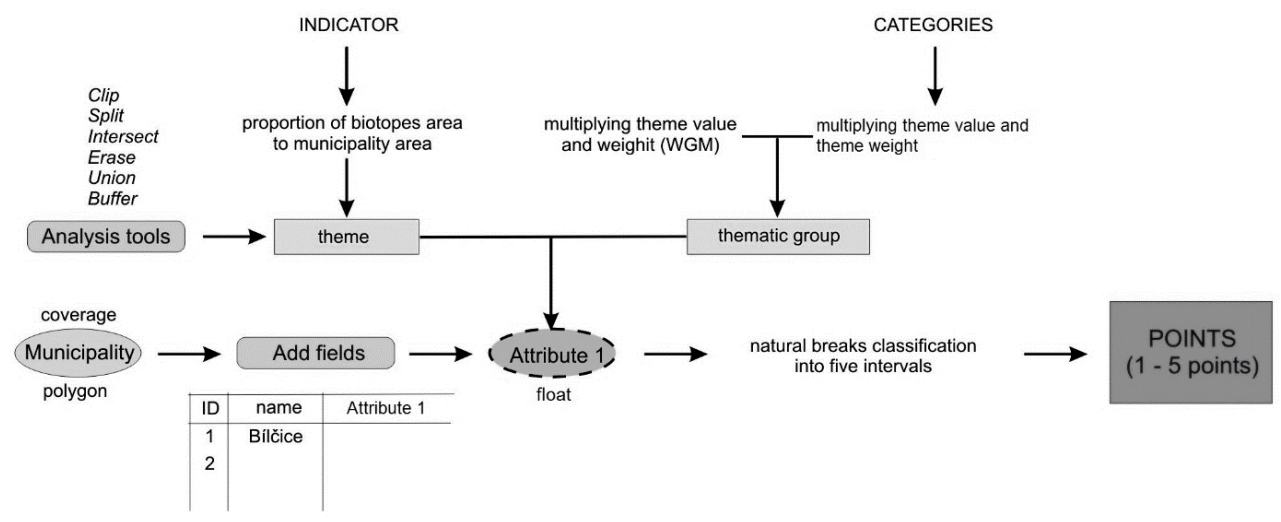

II. Calculation of specific value on the example of Specific environmental area value (SEAV) data set

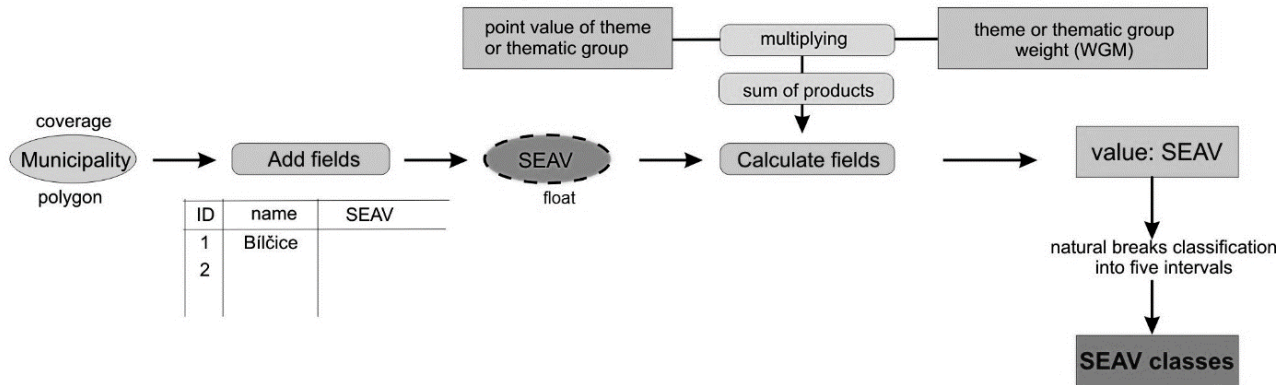

Fig. 1 Data processing flowchart on example of SEAV - specific environmental area value (Ruda, 2014).

The identification of spatial autocorrelation between neighbouring locations can be examined globally using well known indicators of spatial autocorrelation. Besides global measures, local measures of spatial autocorrelation have been developed for identifying the presence of deviations from global patterns and local clusters or local outliers known as "hot spots" (Cliff \& Ord, 1981). The most commonly used spatial autocorrelation statistics is Moran's I coefficient. It belongs to globally statistic measures and its calculation (1) is very similar to Pearson's coefficient:

$$
I=\frac{\sum_{i=1}^{\mathrm{Y}} \sum_{j=1}^{\mathrm{Y}} w_{i j}\left(y_{i}-\hat{y}\right)\left(y_{j}-\hat{y}\right)}{\sum_{i=1}^{\mathrm{Y}} \sum_{j=1}^{\mathrm{Y}} w_{i j}\left(y_{i}-\hat{y}\right)}
$$

where $n$ is the total number of spatial units, $y_{i}$ represents variable in spatial unit $i, \hat{y}$ corresponds to average value of examined variable and $w_{i j}$ defines spatial weight scheme. 
Another approach to measuring spatial association has been introduced by Getis and Ord (1992). Their global spatial association measure (Getis-Ord Gi* statistic) is defined as follows:

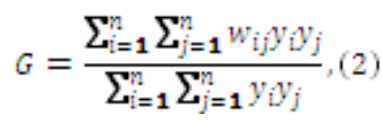

where $n$ is the total number of spatial units, $w_{i j}$ is the $i, j$-th element of a symmetric binary matrix of spatial weights, i.e. $w_{i j}=1$ for neighbouring locations and 0 elsewhere. The statistic in (2) takes values on $[0,1]$, where values close to 1 indicate clustering of high values, while values close to 0 indicate clustering of low values.

Opposite globally oriented measures, local measures of spatial association focus on identifying patterns inside study area. Local Moran's $I_{i}$ is a member of Local Indicators of Spatial Association (LISA) and was developed by Anselin (1995). Calculated values indicate local deviations from global pattern or identify "hot spots" which represent local clusters or significant local outliers. The equation is defined as follows:

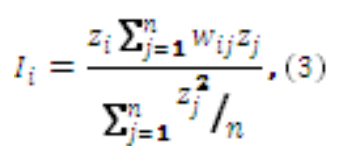

where $z_{i}=\left(y_{i}-\bar{y}\right)$ and $w_{i j}$ is a measure of spatial contiguity between the data sites $i$ and $j$. Large positive $I_{i}$ values inform about local clustering of data value around $i$-th location which deviate from average. Large negative $I_{i}$ values inform that the sign of data value at the $i$-th location is the opposite to those of its neighbours.

Above mentioned analysis were applied by using analytical tools (Grouping Analyses, Hot Spot Analyses,Cluster/Outlier Analyses) in ArcGIS for Desktop 10.2 (ArcGIS). Within cluster/outlier analyses (COType) in ArcGIS, the output field distinguishes between a statistically significant $(0.05$ level) cluster of high values $(\mathrm{HH})$, the output field cluster of low values (LL), outlier in which a high value is surrounded primarily by low values (HL), and outlier in which a low value is surrounded primarily by high values (LH). Using computation in ArcGIS $z$-score and $p$-values are also returned. The $p$-value indicates a probability that the observed spatial pattern was created by some random process. When the $p$-value is very small (less than 0.10 ), it means it is very unlikely (small probability) that the observed spatial pattern is the result of random processes. $z$-scores represent standard deviations. Very high (more than 2.58) or very low (less than -2.58) z-scores, associated with very small $p$-values, are found in the tails of the normal distribution.

\section{STUDY AREA}

Study area is situated in the Nízký Jeseník Highlands in the northern part of Moravia in the Czech Republic (Fig. 2). The area is delineated to encompass a landscape mosaic in which significant contribution to tourism development can also increase a risk of negative impacts. 

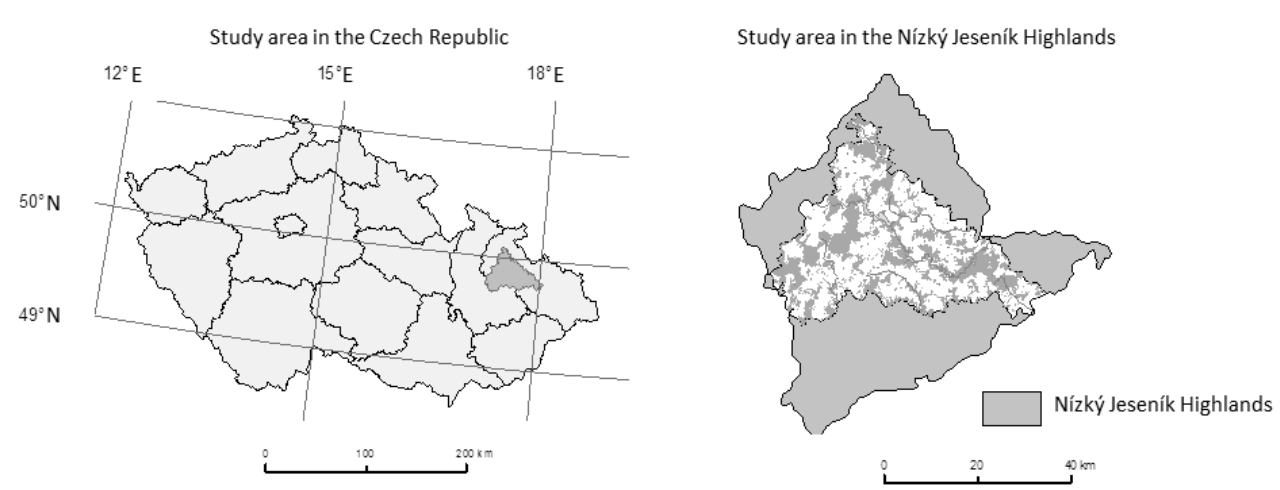

Fig. 2 Localization of study area within Czech Republic and the Nízký Jeseník Highlands.

Considering tourism potential, environmentally valuable area and the position between two stronger tourism destination areas (the Hrubý Jeseník Mountains and the Beskydy Mountains), the study area was delineated approximately between the villages Karlovice Šternberk - Bílovec. 64 cadastral areas (municipalities) were taken into account as examined reference units. Respecting administrative hierarchy, study area is mainly situated in the Moravian-Silesian region, only the southern part extends to the Olomouc region. This makes difficult to develop the Nízký Jeseník Highlands in tourism issues because both regions might have different priorities. Actually the Nízký Jeseník area seems to be more transit region then its neighbours but with respect to its potential for ecotourism activities it is a suitable candidate for this type of research.

\subsection{Specific environmental area value}

Specific environmental area value (SEAV) was proposed as a composite indicator (Fig. 1) reflecting specific value for considering environmental issues within tourism impact assessment (4).

$$
K I_{\text {SEAV }}=\sum V_{\mathrm{i}}\left[\sum_{f=1}^{\mathrm{m}} \mathbb{V}_{\mathrm{i} j} b_{j \mathrm{j}}\right]{ }_{\mathrm{D}}(4)
$$

where $K I_{S E A V}$ is proposed composite indicator, $V_{i}$ represnts $i^{\text {th }}$ weight of the thematic group, $v_{i j}$ is $i^{\text {th }}$ weigth of $j^{\text {th }}$ alternative of assessed atribute and $b_{j}$ corresponds to its assigned point value.

In order to estimate the environmental value for identifying the ratio of environmentally precious areas the approach of predictive model designed by Hammit, Patterson and Noe (1994) was applied. Final value computed by summarizing of partial weighted values (weights are given inside brackets) derived as a theme (coefficient of ecological stability - 0,174), thematic group (protected areas - 0,385, landscape lines 0,057 ) or category (partial indicators within Land use - 0,114 and Habitat catalogue Nature 2000 - 0,269) (Ruda, 2016). 


\subsection{Tourism potential}

The design of tourism potential (TP) is based on Mariot's (1973) proposal and was developed by the similar way as Gunn (1994) developed a tourism planning model using natural and cultural resources. Two prerequisites (realization assumptions, localization assumptions) were considered with equal weight. Realization assumptions consist of accessibility factors (railway stations $-0,085$, bus stations $-0,275$, road network $-0,463$, tourist paths $-0,176$ ) and applicability factors (tourist tracks $-0,242$, showplaces $-0,398$, catering establishment $-0,147$, accommodation facilities $-0,147$ and objects of individual recreation - 0,066). Localization assumptions are completed with natural potential factors (natural remarkableness $-0,225$, suitability for water recreation $-0,048$, suitability for forest recreation $-0,14$, suitability for touring by water $-0,118$, suitability for fishing 0,036 , suitability for protected areas $-0,069$, suitability regarding terrain characteristic 0,341 and other recreation areas - 0,025) and cultural-historical potential (monumental zone $-0,192$, cultural-historical monuments $-0,304$, cultural facilities $-0,054$, church monuments $-0,056$, places of pilgrimage $-0,088$, sport attractions $-0,09$, health provision and wellness $-0,034$ and cultural events $-0,056$ ). Weighted preferences were considered only on the level of factors. The same assessment procedure as in previous data set was applied (5).

$$
\begin{aligned}
& K I_{T P}=I_{L}+I_{R^{v}}(5) \\
& I_{L}=\sum_{\substack{j=1 \\
n}}^{n} \mathbb{W}_{i j} b_{j}(6) \\
& I_{R}=\sum_{j=1}^{\infty} \mathbb{w}_{i j} b_{j}(7)
\end{aligned}
$$

where $K I_{T P}$ is complex composite indicator, $I_{L}$ and $I_{R}$ represent sub indicators ( $L$ for localization assumptions and $R$ for realization assumptions), $v_{i j}$ is $i^{\text {th }}$ weigth of $j^{\text {th }}$ thematic group of assessed atribute and $b_{j}$ corresponds to its assigned point value.

\subsection{Tourism infrastructure load}

Bearing in mind that the lack of data from tourism statistics makes difficult to assess negative tourism impacts and modelling tourism carrying capacity also depends on census data (Lawson et al, 2002; Malik \& Bhat, 2015), a new approach using existing infrastructure has been developed. Considering actual technical infrastructure categories would indirectly help to identify areas with varying density ratio (8).

$$
K I_{T I L}=\sum_{j=1}^{n} \mathbb{V}_{i j} b_{j}(8)
$$

where $K I_{T I L}$ is composite indicator, $v_{i j}$ is $i^{\text {th }}$ weigth of $j^{\text {th }}$ alternative of assessed atribute and $b_{j}$ corresponds to its assigned point value.

Tourism infrastructure load (TIL) is represented by eight themes (weights are given in brackets) 1 . objects of individual recreation $(0.150), 2$. accommodation facilities $(0.150), 3$. road network $(0.314), 4$. railway network $(0.065), 5$. urban areas $(0.165)$, 6. tourist tracks 
(0.097), 7. water sports (0.036), 8. catering facilities (0.024). Although the final value(computed the same way as previous data sets) brings only indirect view on negative influence of tourism in overall assessment TIL plays also an important role.

\section{SPATIAL ASSOCIATIONS OF PROPOSED DATA SETS VALUES}

\subsection{Grouping analysis}

Organizing, grouping or differentiating objects (entities) of the real world is very natural not only for regional development. Based on feature attributes and using geostatistical tools we can perform a classification procedure resulting into finding natural clusters in our data (Assuncao et al, 2006). Feature similarity can be influenced not only by attributes but also by given spatial/time constraints which are in many tools optional. It is obvious that hundreds of cluster analysis algorithms have been developed over past decades. This means that it is also impossible to find grouping algorithm that fits the best for all our purposes because groups are different in sizes, shapes, distribution patterns etc. (Duque, Ramos \& Surinach, 2007). Besides all mentioned aspects, the number of created groups plays another important role. We can directly require to create a given number of groups or to evaluate optimal number of groups which is measured using the CalinskiHarabasz pseudo F-statistic. This value represents a ratio reflecting within-group similarity and between-group differences. Grouping analysis was performed in ArcGIS 10.2. The value of composite indicators computed within all three data sets were used as analysed attributes During the analysis an $R^{2}$ value was computed for each variable. $R^{2}$ value is defined as:

$$
R^{2}=\frac{T S S-E S S}{T S S}(9)
$$

where TSS is the total sum of squares and ESS is the explained sum of squares.

$$
\begin{aligned}
& T S S=\sum_{i=1}^{n_{g}} \sum_{j=1}^{n_{2}} \sum_{k=1}^{n_{l}}\left(V_{i j}^{k}-\overline{V^{k}}\right)^{2} \\
& \text { ESS }=\sum_{i=1}^{n_{l}} \sum_{j=1}^{n_{2}} \sum_{k=1}^{n_{k}}\left(V_{i j}^{k}-\overline{V_{t}^{k}}\right)^{2}
\end{aligned}
$$

where $n$ is the number of features, $n_{i}$ is the number of features in group $i, n_{c}$ is the number of groups, $n_{v}$ is the number of variables used to group features, $V_{\mathrm{i} i \mathrm{j}}^{\mathrm{k}}$ represents the values of the $k^{\text {th }}$ variable of the $j^{\text {th }}$ feature in the $i^{\text {th }}$ group, $\overline{V^{k}}$ represents the mean value of the $k^{\text {th }}$ variable and $\overline{V_{t}^{k}}$ corresponds to the mean value of the $k^{\text {th }}$ variable in group $i$.

The $R^{2}$ indicates which variable divides the features into group more effectively. The larger the $R^{2}$ value is, the effectively the variable determine difference among features. Comparing analysed attributes, Tourism Potential variable has the highest $R^{2}$ value $(0,82)$ indicating more effective influence on grouping process although $R^{2}$ values of other variables are not so different (TIL $-0,74$; SEAV $-0,7$ ). Considering box plot visualization, 
one outlier (Hradec nad Moravicí) has been detected inside tourism potential data set illustrating the strongest position within tourism industry. The appropriate number of groups was examined by pseudo F-statistic parameter also indicating the closest position of its mean and median values. Results indicate that the most effective number for creating groups is two. However, this is not a satisfactory solution. Creating two groups does not give enough opportunities for distinguishing similarities and differences. Therefore other options where mean and median values of pseudo F-statistic parameter get closer were examined. Similar options were found at numbers of 5,9 and 13 groups and based on parallel box plot analysis the most appropriate differences within created groups were indicated at number five. According to this analysis five categories documenting specific relationship between existing tourism potential, its tourism infrastructure load and specific environmental area value have been proposed: area with tourism dominants, unused area with low tourism potential, area with higher load on environmental dominants, unloaded environmentally precious area and ineffectively loaded area (Fig. 3).

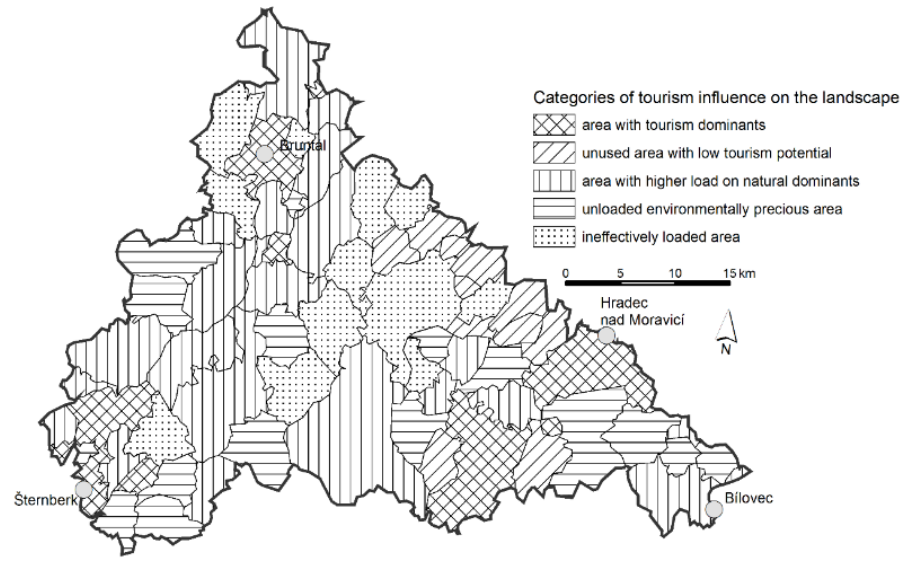

Fig. 3 Qualitative visualization of grouping analyses results.

Parallel box plot of grouped variables (Fig. 4) documents key characteristics of each group.

\section{1 - area with tourism dominants}

Line 1 reflects tracts with average SEAV and the highest values for tourism potential and tourism infrastructure load. Municipalities in this group have high assumptions for tourism development without extreme burden on environment.

\section{2 - unused area with low tourism potential}

Line 2 reflects tracts with the lowest values in all examined indicators. Regions are mostly covered by arable land almost without any usable tourism facility. The development of tourism is not actually recommended although some ecotourism advantages have appeared.

\section{3 - area with higher load on natural dominants}

Regions are covered by the most environmentally precious areas. Line 3 indicates tracts with the highest SEAV and more than the average TP and TIL values. Some areas may be extremely loaded by tourism infrastructure.

\section{4 - unloaded environmentally precious area}


Line 4 reflects tracts with more than average SEAV. TP and TIL values are below average and do not inform about high assumptions for tourism development. Farming and forest management prove environmentally sustainable production in these areas.

\section{5 - ineffectively loaded area}

The group is represented by line 5 connecting more than average TIL values, lower SEAV on the bottom of lower quartile and below average TIL values. Actually hidden tourism potential using neighbours of stronger municipalities may be developed.

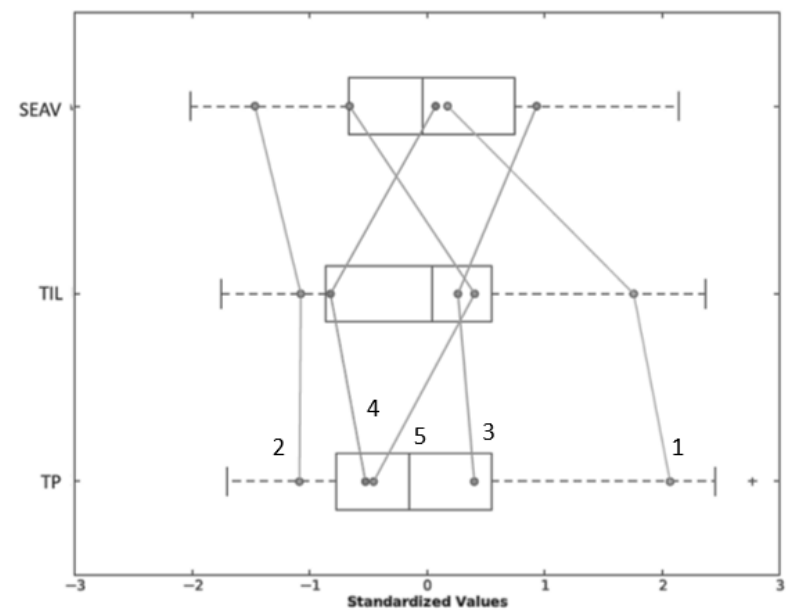

Fig. 4 Parallel box plot of grouped variables: SEAV (Specific Environmental Area Value), TIL

(Tourism Infrastructure Load) and TP (Tourism Potential).

Implementing spatial weights was also examined but with negative result. In order to compare this result with previous results, the number of five groups was set again. The pseudo F-statistic parameter returned also two groups as the most effective solution but opposite to previous results decreasing value of parameter for increasing number of groups was achieved. Furthermore, created groups have extremely clustered with high range of values within each indicator. In this case, non-spatial grouping brings much more relevant results applicable in regional development.

\subsection{Spatial autocorrelation}

Given a set of features and an associated attribute, the Spatial Autocorrelation tool evaluates whether the pattern expressed is clustered, dispersed, or random.

Tabel 1. Global Moran's statistic.

Legend: TP (Tourism Potential), TIL (Tourism Infrastructure Load), SEAV (Specific Environmental Area Value)

\begin{tabular}{l|ccccc}
\hline $\begin{array}{c}\text { analysis } \\
\text { attribute }\end{array}$ & Moran's I index & z-score & p-value & spatial pattern & $\begin{array}{c}\text { distance threshold } \\
(\mathrm{m})\end{array}$ \\
\hline SEAV & 0.6351 & 8.172512 & 0 & CLUSTERED & 14360 \\
TP & 0.134982 & 1.895836 & 0.057982 & CLUSTERED & 8360 \\
TIL & 0.063591 & 0.983574 & 0.325325 & RANDOM & 14360 \\
\hline
\end{tabular}


The Spatial Autocorrelation tool using the Global Moran's I statistic returns five values: the Moran's I Index, Expected Index, Variance, z-score, and p-value. Z-score and pvalue indicates whether or not you can reject the null hypothesis. In this case, the null hypothesis states that feature values are randomly distributed across the study area. When the $\mathrm{z}$-score or p-value indicates statistical significance, a positive Moran's I index value indicates tendency toward clustering while a negative Moran's I index value indicates tendency toward dispersion (Mitchel, 2005). Tab. 1 documents that SEAV has very high zscore value when using $100 \%$ confidence level (p-value associated with a 100 percent confidence level is 0.00). The observed spatial pattern is clustered and in this case, it is possible to reject the null hypothesis. The distance threshold for following cluster analysis is 14360 metres. TP values also proved a clustered pattern when using $95 \%$ confidence level with z-score 1.89 and distance threshold 8360 meters.Opposite to previous attribute values TIL values showed random distribution and also acceptance of null hypothesis. The general Getis-Ord Gi* statistic has been calculated by Hot Spot Analysis tool to delineate the areas based on whether large number of municipalities tends to cluster in study area or not. Considering SEAV, one hot spot and one cold spot have been identified (Fig. 5).

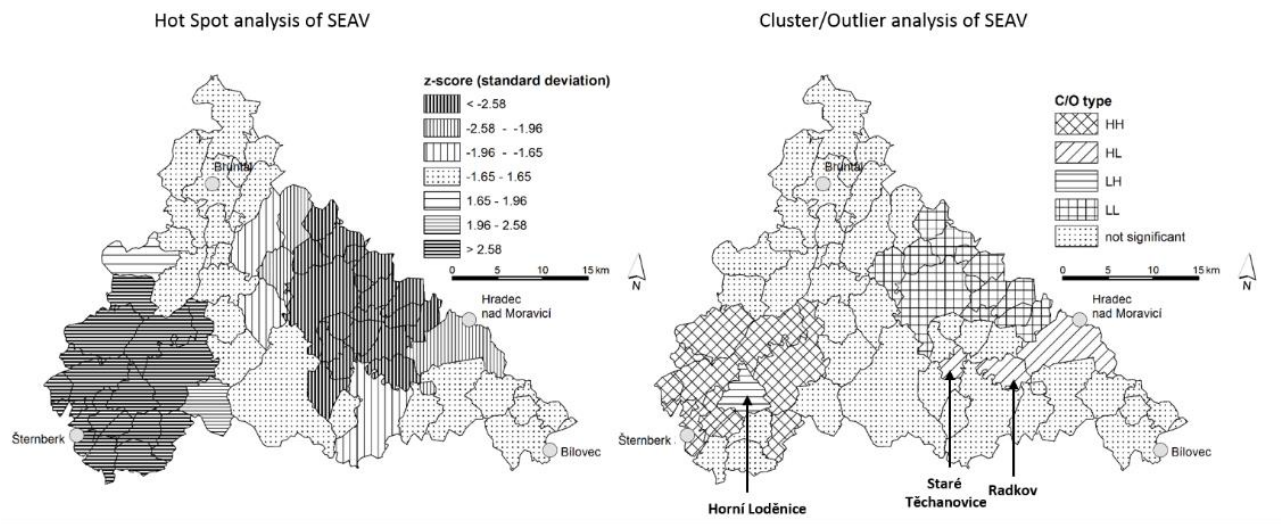

Fig. 5 Spatial autocorrelation analysis of SEAV.

Municipalities with z-score more than 2.58 have been considered to significant at $95 \%$ confidence level and put in the hot spot category. This hot spot with 16 municipalities is observed around Sternberk in the south-western part and deserves attention in terms protecting the nature with environmentally precious areas. Cold spot near Hradec nad Moravicí represents area mostly covered by arable land used for farming with minimum of environmentally precious areas. Cluster/outlier analyses returned much detailed results allowing to highlight one weaker municipality (LH type: Horní Loděnice) in case of SEAV hot spot which are surrounded by municipalities with higher SEAV (HH type). Analysing cold spot, three dominant municipalities (Hradec nad Moravicí, Radkov, Staré Těchanovice) with higher and surrounded by municipalities with lower SEAV (HL type) were identified (Fig. 5). These results illustrate local differences inside clustered area. Similarly as in previous case, in case of tourism potential values Hot Spot analysis using Getis-Ord Gi* statistic delineated one hot spot around Bruntál and one cold spot between Bruntál and Hradec nad Moravicí (Fig. 6). The values of local Morans's I statistic distinguished $\mathrm{HH}$ C/O type in Bruntál directly bordering with LH C/O type in Staré Město 
representing an observed outlier. Another important node for weak regions was identified in Hradec nad Moravicí (HL C/O type) (Fig. 6).
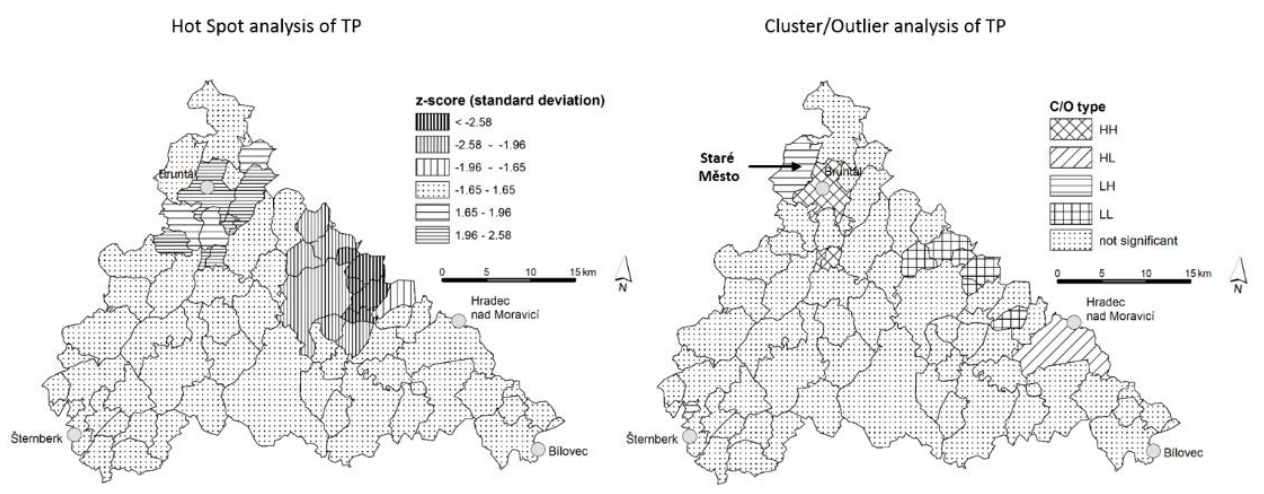

Fig. 6 Spatial autocorrelation analysis of TP.

\section{CONCLUSION REMARKS}

The paper highlights the asset of spatial data analysis techniques to detect regions with significant deviations in order to determine the intensity of interactions between neighbouring municipalities in selected area of the Nízký Jeseník Highlands. The proposal of mentioned indices (data sets) was based on available data and expert preferences. Considering partial results, the highest tourism potential is concentrated near nodal regions (Šternberk, Bruntál and Hradec nad Moravicí). These municipalities were also identified as potential tourism development cores. Besides Šternberk and Bruntál have also significant environmental value with higher infrastructure load. On the contrary, municipalities oriented to agriculture extend from Bruntál to Hradec nad Moravicí and although they are weak in tourism potential agriculture represents their hopeful beginning in ecotourism. Applied approach for identifying spatial patterns revealed that spatial statistics tools can not be used automatically in order to get satisfying results because the existing spatial pattern decides if following analyses are valid or not. Modelling different approaches in grouping analysis confirmed that considered spatially-based approach did not result into satisfying proposal of community groups. Using non-spatial approach enabled to create five optimal specific groups partly sharing borders which may be used for community planning in tourism. Unloaded environmentally precious areas still wait for tourism infrastructure development using the position of stronger neighbours.

\section{R E F E R E N C E S}

Anselin, L. (1995) Local indicators of spatial association - LISA. Geographical Analysis, 27(2), 93115.

Assuncao, R. M., Neves, M. C., Camara, G. \& Da Costa Freitas, C. (2006) Efficient Regionalisation Techniques for Socio-economic Geographical Units using Minimum Spanning Trees. International Journal of Geographical Information Science, 20(7), 797-811.

Bína, J. (2010) Aktualizace potenciálu cestovního ruchu v České republice. Retrieved from<http://www.uur.cz/images/uzemnirozvoj/cestovniruch/potencialCR/PotencialCR-text.pdf> 
Boyd, J. \& Banzhaf, S. (2007) What are ecosystem services? The need for standardized environmental accounting units. Ecological Economics, 63(2-3), 616-626.

Buijs, A. E., Pedroli, B. \& Luginbühl, Y. (2006) From hiking throough farmland to farming in a leisure landscape: changing social perceptions of the European landscape. Landscape ecology, 21(3), 375-389.

Butler, R. W. (1999) Sustainable tourism: A state-of-the-art review. Tourism Geographies, 1(1), 7-25.

Butler, R. W. (1993) Tourism - an evolutionary perspective. In: Nelson, J.G. et al. (Eds.), Tourism and Sustainable Development: Monitoring, Planning, Managing (pp. 27-44).Ontario: University of Waterloo.

Cliff, A. D. \& Ord, J. K. (1981) Spatial processes - models and applications. London: Pion.

Corodescu, E. (2016). GIS approaches in assessing the rural space accessibility - case study: Vaslui county, Romania. Geographia Technica, 9(1), 22-30.

Deng, J., King, B. \& Bauer, T. (2002) Evaluating natural attractions for tourism. Annals of Tourism Research, 29 (2), 422-438.

Duffield, B. S. \& Coppock, J. T. (1975) The delineation of recreational landscapes: the role of a computer based information system. Transaction of the Institute of British Geographers, 66(2), 141-148.

Duque, J. C., Ramos, R. \& Surinach, J. (2007) Supervised Regionalization Methods: A Survey. International Regional Science Review, 30(3), 195-220.

Egresi, I. \& Kara, F. (2015) Predictors of tourists' shopping propensity: a case from Istanbul. Geographia Technica, 10(2), 29-40.

Faggi, A., Breuste, J., Madanes, N., Gropper, C., Perelman, C. (2011) Water as an appreciated feature in the landscape: a comparison of residents' and visitors'preferences in Buenos Aires. Journal of Cleaner Production, 60(1): 1-6.

Fortin, M. J. \& Dale, M. R. T. (2009) Spatial autocorrelation. In: Fotheringham, A., Rogerson, P. A. (Eds.), The SAGE Handbook of Spatial Analysis (pp. 89-104). London/Thousand Oaks/New Delhi/Singapore: SAGE publication.

Getis, A. \& Ord, J. K. (1992) The analysis of spatial association by use of distance statistics. Geographical Analysis, 24(3), 189-206.

Gobster, P. H., Gimblett, H. R. \& Kelley, B. B. (1987) Modeling forest recreational policy alternatives: a geographic information systems approach. In Proceedings of GIS 87(pp. 101111). Falls Church: American Society for Photogrammetry and Remote Sensing.

Gobster, P. H. (2001) Visions of nature: conflict and compatibility in urban park restoration. Landscape and Urbam Planning, 56(1-2), 35-51.

Gunn, C. A. (1994) Tourism Planning: Basics, Concepts, Cases. Washington: Taylor and Francis.

Haines-Young, R. \& Potschin, M. (2011) Common International Classification of Ecosystem Services (CICES): 2011 Update. European Environment Agency.

Hammit, W. E., Patterson, M. E. \& Noe, F. P. (1994) Identifying and predicting visual preference of Southern Appalachian forest recreation vistas. Landscape and Urban Planning, 29(2-3), 171183.

Chhetri, P. \& Arrowsmith, C. (2008) GIS-based modelling of recreational potential of nature-based tourist destinations. Tourism geographies, 10(2), 233-257.

Kliskey, A. D. (2000) Recreation terrain suitability mapping: a spatially explicit methodology for determining recreation potential for resource use assessment. Landscape and Urban planning, 52(1), 33-43.

Lawson, S., Manning, R.,Valliere,W.,Wang, B. \& Budtruk, M. (2002) Using simulating modelling to facilitate proactive monitoring and adaptive management of social carrying capacity in Arches National Park, Utah, USA. In A. Arnberger, C. Brandenburg \& A. Muhar (Eds.), Monitoring and Management of Visitor Flows in Recreational and Protected Areas (pp. 205-210).Vienna: Bodenkutur University. 
Leopold, L. B. (1969) Landscape Aesthetic. Natural History, 78(4), 37-44.

Levinsohn, A., Langford, G., Rayner, M., Rintoul, J. \& Eccles, R. (1987) A micro-computer based GIS for assessing recreation suitability. In Proceedings of GIS 87 (pp. 739-747). Falls Church: American Society for Photogrammetry and Remote Sensing.

Magyari-Sáska, Z. (2014) Quantifying threats along tourist trails: an initial approach. Geographia Technica, 9(1), 78-86.

Malik, M. I. \& Bhat M. S. (2015) Sustainability of tourism development in Kashmir - Is paradise lost? Tourism management perspectives, 16(1), 11-21.

Manly, B. F. J. (2004) Multivariate Statistical methods: A Primer. New York: Chapman and Hall.

Mariot, P. (1969) Príspevok k metódevýzkumupotenciekrajiny $\mathrm{z}$ hladiskacestovnéhoruchu. Geografickýčasopis, 21(1), 57-73.

Mariot, P. (1971) Funkčné hodnotenie predpokladov cestovného ruchu ako podklad pre vytvorenie priestorového modelu cestovného ruchu. Geografický časopis, 23(3), 242-253.

Mariot, P. (1973) Metodické aspekty funkčno-chorologického honotenia lokalizačných predpokladov cestovného ruchu.Geografický časopis, 25(1), 27-43.

McHarg, I. (1969) Design with nature. The Natural History Press: Garden City.

Miller, D.R., Aspinall, R.J. \& Morrice, J.G. (1992) Recreation potential and management in the Cairngorms: use of GIS for analysis of landscape in an area of high scenic value. In J. CadouxHudson \& I. Heywood, (Eds.), Geographic Information 1992/93 - Yearbook of the Association for Geographic Information (pp. 82-92). London: Taylor and Francis.

Mitchell, A. (2005) The ESRI Guide to GIS Analysis. Redlands: ESRI Press.

Nahuelhual, L., Carmona, A., Lozada, P., Jaramillo, A. \& Aguayo, M. (2013) Mapping recreation and ecotourism as a cultural ecosystem service: An application at the local level in Southern Chile. Applied geography, 40, 71-82.

Ruda, A. (2010) Contribution to assessement of the tourism impact on landscape. Acta Universitatis Carolinae Geographica, 45(1), 61-74.

Ruda, A. (2011) Selected chapters from the new economy. E \& M EKONOMIE A MANAGEMENT, $14(1), 135-135$.

Ruda, A. (2013) The organization and administration of GIS in regional offices. In V. Klimova \& V. Zitek (Eds.), 16th International Colloquium on Regional Sciences(pp. 444-450). Brno: Masaryk University.

Ruda, A. (2014) Environmental Potential Identification on the Example of the Nízký Jeseník Highlands. Acta Universitatis Agriculturaeet Silviculturae Mendelianae Brunensis, 62(5), 10951112.

Ruda, A. (2016) Spatial decision support: the example of the conflict between landscape protection and tourism development. Journal of Maps,[Online] Retrieved from http://www.tandfonline.com/doi/abs/10.1080/17445647.2016.1152915.

Ruda, A. Pokladníková, M. (2016) Map algebra in tourism potential modelling for improving social issues in Masaryk's school forest enterprise Křtiny. Geographia Technica, 11(1), 67-83.

Tobler, W.R. (1970) A computer movie simulating urban growth in the Detroit Region. Economic geography, 46, 234-240.

USDA Forest Service. (1989) North Central Forest Experiment Station Forest Inventory and Analysis Field Manual, USDA Forest Service North Central Forest Experiment Station Forest.

Weyland, F. \& Lattera, P. (2014) Recreation potential assessment at large spatial scales. A method based in the ecosystem services approach and landscape metrics. Ecological indicators, 39, 34 43. 